\title{
PENGARUH PASANGAN MEMILIKI PASANGAN SEKS LAIN TERHADAP KEJADIAN INFEKSI HIV PADA IBU RUMAH TANGGA DI RSUPH. ADAM MALIK MEDAN TAHUN 2017
}

\author{
Aprilita Sitepu \\ Staff Pengajar STIKes Santa Elisabeth Medan
}

\begin{abstract}
ABSTRAK
Latar Belakang : Infeksi HIV (human immunodeficiency virus) dan AIDS (acquired immunodeficiency syndrome) merupakan masalah kesehatan masyarakat global. Penderita HIV di Indonesia yang paling banyak berasal dari kelompok Ibu Rumah Tangga.

Tujuan : Penelitian ini bertujuan untuk mengetahui pengaruh pasangan memiliki pasangan seks lain terhadap kejadian infeksi HIV pada Ibu rumah Tangga di RSUP H. Adam Malik Medan.

Metode : Penelitian ini bersifat analitik observasional dengan desain case control. Penelitian dilakukan di RSUP H Adam Malik Medan dari Bulan November sampai Desember 2017. Populasi penelitian ini seluruh Ibu rumah tangga yang terinfeksi HIV. Kasus adalah ibu rumah tangga yang terinfeksi HIV sebesar 40 responden dan kontrol adalah ibu rumah tangga yang tidak terinfeksi HIV sebesar 40 responden. Variabel dependen adalah Kejadian Infeksi HIV pada Ibu Rumah Tangga, variabel independen pasangan memiliki pasangan seks lain.

Hasil : Hasil penelitian menunjukkan ada pengaruh pasangan memiliki pasangan seks lain $(\mathrm{OR}=6.223)$ terhadap kejadian HIV pada Ibu rumah tangga di RSUP H Adam Malik Medan.

Kesimpulan : Pasangan yang pernah memiliki pasangan seks lain meningkatkan kejadian HIV dan berpengaruh signifikan secara statistik.
\end{abstract}

Kata Kunci : HIV, ibu rumah tangga, pasangan memiliki pasangan seks lain

\section{ABSTRACT}

Background: HIV infection and AIDS are the global public health problem. Having another sex partner may increase the risk of HIV infection.

Goals : This study aimed to determine the effect of having another sex partner on the incidence of HIV infection in couples in Medan.

Method: This was an analytic observational study with a case-control design. The study was conducted at RSUP H Adam Malik Medan, North Sumatera, from November to December 2017. A sample of 80 housewives was selected for this study by fixed disease sampling consisting of $40 \mathrm{HIV}$ infected housewives and $40 \mathrm{HIV}$ uninfected housewives. The dependent variable was HIV infection. The independent variable was having another sex partner.

Results: The results of multivariate analysis demonstrated that husband's occupation $(O R=6.223)$, having another sexual partner $(O R=6.823)$ Conclusion: Couples who have another sexual partner have an increased risk of HIV infection.

Keywords: HIV, housewive, having other sex partner

Pendahuluan

Infeksi HIV (Human

Immunodeficiency Virus) dan AIDS
(Acquired Immunodeficiency Syndrome) saat ini merupakan masalah kesehatan masyarakat global (seluruh dunia) 
(WHO, 2016) dan merupakan salah satu dari permasalahan kesehatan reproduksi (Yanti, 2011). Penyakit ini juga memiliki "window periode" dan fase asimptomatik (tanpa gejala) yang relatif panjang dalam perjalanan penyakitnya, hal tersebut menyebabkan pola perkembangannya seperti Fenomena Gunung Es (iceberg phenomena). Dalam ruang lingkup kesehatan reproduksi, HIV/AIDS merupakan penyakit menular seksual yang memerlukan perhatian yang sangat serius. Ini terlihat dari jumlah kasus HIV/AIDS yang dilaporkan setiap tahunnya meningkat secara signifikan (Pratiwi, D.W, 2015).

Berdasarkan

perkiraan

UNAIDS/WHO tahun 2016, ditemukan bahwa orang yang hidup dengan HIV mencapai 34 juta orang. Dengan perkiraan proporsi orang dewasa khususnya yang menderita ditemukan $50 \%$ adalah perempuan. Sedangkan anak-anak yang hidup dengan HIV mencapai 3.4 juta orang (UNAIDS, 2016).

Menurut UNAIDS epidemik yang paling tinggi di dunia adalah di Afrika Selatan, dengan estimasi 5,6 juta orang di Afrika Selatan orang hidup dengan HIV. Hampir setengah dari kematian akibat penyakit terkait AIDS pada tahun 2015 terjadi di Afrika Selatan. Negara Karibia, merupakan prevalensi tertinggi kedua daerah HIV setelah sub Sahara Afrika serta Negara Asia dikelompokkan dalam Negara kedua terbesar orang yang hidup dengan HIV, infeksi HIV baru di Eropa timur dan Asia Tengah meningkat sebesar 57\% (UNAIDS, 2016). Tujuan Pembangunan Berkelanjutan atau Sustainable Development Goals (SDG's) adalah menghentikan epidemi AIDS, tuberkulosis, malaria, dan penyakit menular lainnya di dunia pada 2030 (Kemenkes RI, 2016).

Berdasarkan data Kemenkes RI, 2016, hingga saat ini HIV sudah menyebar di $368 \quad(72 \%)$ dari 497 kabupaten/kota di seluruh provinsi Indonesia. Jumlah kasus HIV tertinggi yaitu DKI Jakarta (4.402 kasus), diikuti Jawa Timur (4.063 kasus), Jawa Barat (3.602 kasus) Papua (2.591 kasus), Jawa Tengah (2.875 kasus), Bali (1.726 kasus), Sumatera Utara (1.357 kasus), Sulawesi Selatan (733 kasus), Maluku (394 kasus). Penderita HIV di Indonesia yang paling banyak berasal dari kelompok Ibu Rumah Tangga (6.539 kasus). Angka kasus ini lebih besar jika dibandingkan dengan kelompok penjaja seks, yaitu sebanyak 2.052 kasus (Kementrian Kesehatan RI0, 2016).

Salah satu provinsi yang terbesar yang memiliki kasus HIV pada Ibu rumah tangga adalah Provinsi Sumatera Utara mencapai peringkat ketiga sejumlah 617 orang dengan proporsi $(11,5 \%)$. Lalu menyusul karyawan 348 orang dengan proporsi sebesar $(6,49 \%)$, narapidana 202 orang proporsi sebesar $(3,7 \%)$, pekerja seks komersial (PSK) 179 orang proporsi sebesar (3,3\%), PNS/Polri 166 orang $(3,09 \%)$, serta mahasiswa dan pelajar 96 orang (1,79\%) (KPA SUMUT, 2016).

Peningkatan jumlah penderita infeksi HIV pada Ibu Rumah Tangga yang semakin meningkat juga dapat dilihat di Rumah Sakit Umum Pusat H. Adam Malik Medan, karena rumah sakit ini merupakan rumah sakit kelas tipe A sebagai pusat rujukan terakhir dari rumah sakit lainnya yang menyediakan pelayanan bagi penderita HIV/AIDS di Provinsi Sumatera Utara. dari data yang diperoleh catatan rekam medik penderita HIV/AIDS yang dirawat di Rumah Sakit Umum Pusat Haji Adam Malik Medan dari beberapa kasus HIV yang menjalani perawatan pada perempuan tahun 2014 ditemukan 108 kasus (Ibu Rumah Tangga 59 orang $(54,62 \%)$ diikuti wiraswasta 37 orang $(34,26 \%)$, petani 4 orang $(3,7 \%)$ dan PNS 8 orang $(7,7 \%)$ tahun 2015 terjadi penurunan menjadi 97 kasus (Ibu Rumah Tangga 30 orang $(31 \%)$, wiraswasta 21 orang $(21,69 \%)$, petani 29 orang $(29,90 \%)$ dan PNS 17 orang $(17,52 \%)$ dan 2016 terjadi peningkatan lagi menjadi 127 kasus (Ibu Rumah Tangga 54 orang $(42,52 \%)$, wiraswasta 
36 orang $(28,35 \%)$, petani 16 orang $(12,60 \%)$, dan PNS 21 orang $(16,54 \%)$, dengan populasi ibu Rumah Tangga penderita HIV ditemukan 54 orang. Sehingga dapat di akumulasikan jumlah penderita HIV pada Ibu rumah tangga dari tahun 2014 sampai tahun 2016 sejumlah 450 orang (Sistem informasi RSUP H. Adam Malik Medan).

Dari hasil wawancara yang dilakukan kepada 10 ibu rumah tangga yang datang melakukan pengobatan ke RSUP.H Adam Malik Medan 10 orang mengatakan tidak mengetahui apa yang menjadi penyebab dia sakit, dilihat dari latar belakang pendidikan 2 orang ibu mengatakan hanya lulus SLTP, 3 orang mengatakan suami bekerja sebagai supir dan ketika berhubungan seksual tidak menggunakan kondom, 3 orang mengatakan suami pernah sebagai pengguna jarum suntik, dan 2 orang mengatakan pernah transfusi darah, sehingga peneliti tertarik untuk mengetahui Faktor - Faktor yang memengaruhi kejadian infeksi HIV pada Ibu Rumah Tangga di RSUP H. Adam Malik Medan Tahun 2017.

\section{Metode Penelitian}

Jenis penelitian yang digunakan adalah studi analitik dengan desain studi case control. Lokasi penelitian ini dilakukan di RSUP H. Adam Malik Medan. Pemilihan lokasi di RSUP H. Adam Malik Medan. Populasi kasus dalam penelitian ini adalah seluruh ibu rumah tangga yang sudah melakukan pemeriksaan laboratorium dan hasil diagnosis terinfeksi HIV yang diperoleh dari catatan rekam medik di poli pelayanan khusus di RSUP H. Adam Malik Medan. Kasus adalah Ibu Rumah Tangga yang terinfeksi HIV sebesar 40 responden dan kontrol adalah Ibu Rumah Tangga yang tidak terinfeksi HIV sebesar 40 responden atau dengan perbandingan 1:1. Data dianalisa secara bivariat dengan uji regresi logistik sederhana dan multivariat dengan uji regresi logistik berganda pada $\alpha 5 \%$.
Analisis Univariat Tabel 1 Karakteristik Responden

\begin{tabular}{lllll}
\hline \multirow{2}{*}{$\begin{array}{c}\text { Karakteristik } \\
\text { Responden }\end{array}$} & \multicolumn{3}{c}{ Status Responden } \\
\cline { 2 - 5 } & \multicolumn{2}{c}{ Kasus } & \multicolumn{2}{c}{ Kontrol } \\
\cline { 2 - 5 } & $\mathbf{n}$ & $\mathbf{\%}$ & $\mathbf{n}$ & $\mathbf{\%}$ \\
\hline Suami Memiliki Pasangan Seks Lain & \\
$\begin{array}{l}\text { Berisiko (suami yang } \\
\text { memiliki pasangan }\end{array}$ & 28 & 70,0 & 16 & 40,0 \\
seks selain istri) & & & & \\
$\begin{array}{l}\text { Tidak Berisiko (suami } \\
\text { yang tidak memiliki } \\
\text { pasangan seks lain } \\
\text { selain istri) }\end{array}$ & 30,0 & 24 & 60,0 \\
\hline
\end{tabular}

Pada tabel 1 kelompok kasus diatas suami memiliki pasangan seks lain yaitu sebanyak 28 orang (70,0\%).

Mayoritas ibu rumah tangga pada kelompok kontrol adalah suami tidak memiliki pasangan seks lain yaitu sebanyak 24 orang $(60,0 \%)$.

Analisis Bivariat

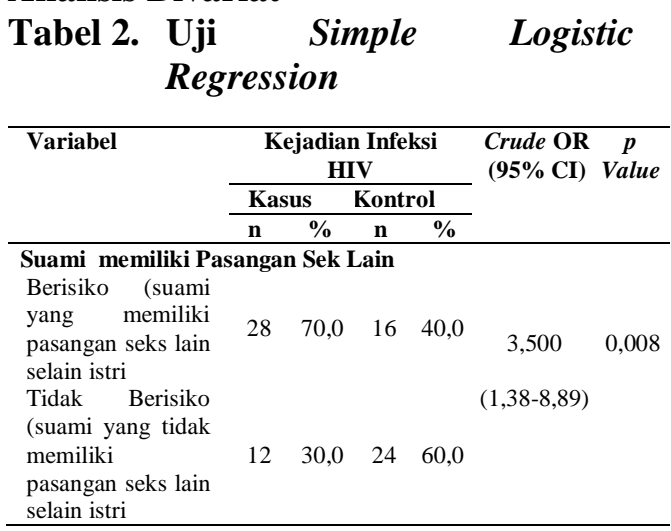

Berdasarkan hasil analisa bivariat dengan menggunakan uji simple logistic regression maka semua variabel yang terdiri dari umur, pendidikan, pekerjaan suami, suami memiliki pasangan seks lain, pengguna narkoba jarum suntik, riwayat transfusi darah, dan riwayat penyakit menular seksual suami memiliki nilai $\mathrm{p}<0,25$ sehingga dapat masuk dalam pemodelan analisis multivariat dan dilakukan uji multiple logistic regression dengan metode enter, farward, backward dan stepwise. 
Analisis Multivariat

\begin{tabular}{|c|c|c|c|c|c|}
\hline Tabel 3. & $\begin{array}{l}\text { Mod } \\
\text { Pers } \\
\text { Logi }\end{array}$ & $\begin{array}{l}\text { lel } \\
\text { ama } \\
\text { stik }\end{array}$ & $\mathbf{n}^{\mathbf{A k}}$ & nir & $\begin{array}{r}\text { untu } \\
\text { Regres }\end{array}$ \\
\hline \multirow{2}{*}{ Variabel } & \multirow[t]{2}{*}{ 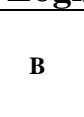 } & \multirow{2}{*}{ Sig. } & \multirow{2}{*}{ OR } & \multicolumn{2}{|c|}{ 95\% C.I } \\
\hline & & & & Lower & Upper \\
\hline $\begin{array}{l}\text { Pasangan } \\
\text { memiliki } \\
\text { pasangan lain }\end{array}$ & 1,920 & 0,002 & 6,823 & 1,985 & 23,45 \\
\hline
\end{tabular}

Uji Regresi Logistik Berganda dengan metode farward $L R$ Uji Multikolinearitas nilai VIF <10, Hosmer and Lameshow $=0,531$, Classification Table 73,8\%, ROC Curve 82,3\%

Pengaruh Suami Memiliki Pasangan Seks Lain terhadap Kejadian Infeksi HIV pada Ibu Rumah Tangga di RSUP. H Adam Malik Medan Tahun 2017

Hasil analisis multivariat juga menunjukkan bahwa ada pengaruh antara pasangan memiliki pasangan seks lain dengan kejadian HIV $\mathrm{p}=0,002$ $(p<0,05)$ dengan nilai $\mathrm{OR}=6,823$, hal ini berarti variabel suami memiliki pasangan seks lain berpengaruh secara signifikan terhadap kejadian HIV pada ibu rumah tangga, bahwa ibu rumah tangga yang memiliki suami mempunyai pasangan seks lain 6,823 kali kemungkinan untuk menderita HIV dibandingkan ibu rumah tangga yang memiliki suami tidak ada pasangan seks lain selain istri.

Sejalan dengan penelitian Saleh (2012) menunjukkan terdapat hubungan $(p=0,000)$ antara jumlah pasangan seksual dalam 6 bulan terakhir dengan status HIV. Hal ini dapat terjadi dikarenakan infeksi HIV pada usia muda berhubungan dengan banyaknya pasangan seksual mereka.

\section{KESIMPULAN DAN SARAN}

\section{Kesimpulan}

Berdasarkan hasil analisis dan pembahasan penelitian, maka dapat diambil kesimpulan sebagai berikut:

1. Terdapat pengaruh yang signifikan antara pasangan memiliki pasangan seks lain terhadap kejadian infeksi
HIV pada Ibu Rumah Tangga di RSUP. H Adam Malik Medan Tahun 2017, dengan nilai $p$ value $0,002 \quad(p<0,05)$. Hasil nilai prevalensi ratio sebesar 6,823 menunjukkan bahwa kejadian infeksi HIV pada ibu rumah tangga yang memiliki memiliki suami yang mempunyai pasangan seks lain berisiko 6,823 kali lebih besar mengalami infeksi HIV dibandingkan dengan ibu rumah tangga yang tidak memiliki suami yang mempunyai pasangan seks lain.

\section{Saran}

1. Kepada Dinas Kesehatan Kota Medan diharapkan meningkatkan ketelitian pencatatan penderita HIV pada Ibu rumah tangga dengan lebih intensif seperti; pencatatan data bulanan, tahunan sampai dengan akumulasi, sehingga keakuratan lebih baik serta terpublikasi dan bekerjasama dengan Komisi Penanggulangan AIDS (KPA), Lembaga Swadaya Masyarakat (LSM) dalam upaya promosi pencegahan, perawatan serta dukungan pada penanggulangan HIV khususnya bagi Ibu Rumah Tangga yang terinfeksi HIV maupun Ibu rumah tangga yang belum terinfeksi HIV.

2. Kepada poli pelayanan khusus RSUP H Adam Malik Medan agar meningkatkan dan memperkuat layanan VCT, bekerjasama dengan semua jajaran sector kesehatan dan lintas program preventif, promotif, dan rehabilitative untuk memperkuat konsolidasi dan koordinasi dalam penanggulangan HIV terhadap keterbatasan yang diberikan lingkungan seperti stigmatisasi dan diskriminasi terutama pada Ibu Rumah Tangga.

3. Kepada Masyarakat khususnya Ibu rumah tangga tumbuhkan semangat hidup dan berjuang melawan virus HIV bagi yang sudah terinfeksi, sikap terbuka akan lebih mudah 
untuk proses penyembuhan dan menahan virus tidak semakin menyebar. Memperkuat norma nilainilai positif dalam keluarga, serta setia terhadap pasangan yang telah dimiliki tanpa mencari pasangan seks lain terutama bagi ibu rumah tangga yang memiliki suami yeng bekerja diluar dan jarang kembali kerumah seperti supir untuk senantiasa mengingatkan para suami agar menjaga diri untuk dirinya dan istrinya yang berada dirumah agar terjaga keluarga yang harmonis.

4. Kepada petugas kesehatan agar dalam menjalankan tugasnya melayani Pasien-pasien yang terinfeksi HIV tetap selalu menggunakan alat pelindung diri (APD) agar terhindar dari pencegahan Infeksi HIV.

\section{DAFTAR PUSTAKA}

Dinas Kesehatan Provinsi Sumatra Utara.2015, Profil Kesehatan Provinsi Sumatra Utara Tahun 2014, Dinas Kesehatan Provinsi Sumatra Utara, Medan.

Djuanda. 2008. Modeling HIV/AIDS Prevention by Defense, "International Journal of Biological and Life Science 4 (2). pp. 71-75.

Kementerian Kesehatan RI, 2016. Laporan Perkembangan HIV/AIDS Triwulan III Tahun 2016. Jakarta: Direktorat Jenderal Pengendalian Penyakit dan Penyehatan Lingkungan.

Pratiwi, D.W., 2015. Pencegahan Penularan HIV Perempuan Pasangan Pengguna Narkoba Suntik Di Kota Semarang. Jurnal Permata Indonesia, Vol 6, No.1, Mei 2015 : 9-20.
UNAIDS, 2016.World Aids day Report. Joint Unites Nations Programme on HIV/AIDS (UNAIDS)

WHO, 2016.http://www.who.int/ mediacentre/factsheets/fs360/en/ 